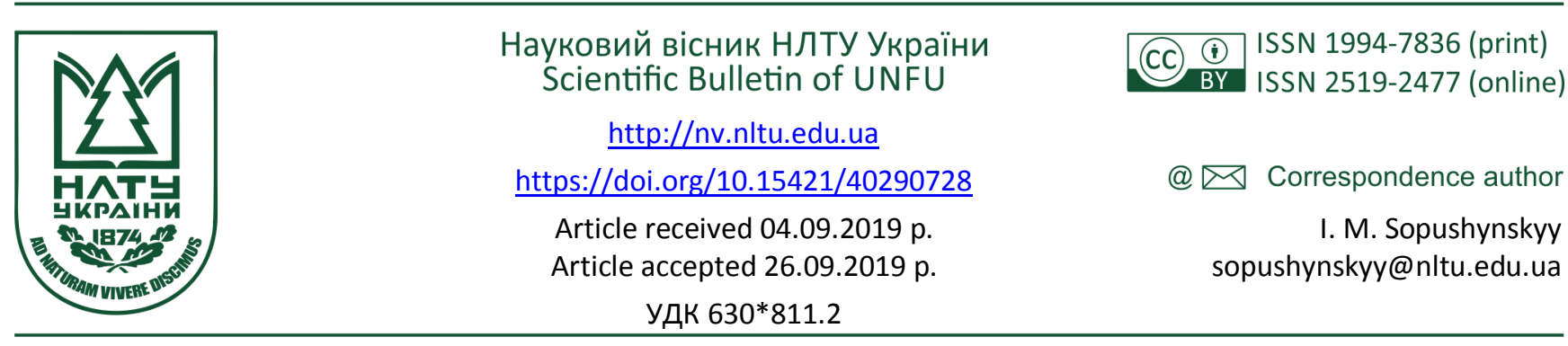

I. М. Сопушинський, Я. М. Кополовець

Національний лісотехнічний університет Украйни, м. Львів, Украӥна

\title{
КВАЛІМЕТРІЯ ЛІСОМАТЕРІАЛІВ ЯЛИЦІ БІЛОЇ В УКРАЇНСЬКИХ КАРПАТАХ
}

Вивчено розмірно-якісні характеристики стовбурної деревини ялиці білої в експлуатаційних лісах Тур'я-Реметівського та Порошківського лісництв ДП "Перечинське лісове господарство". Кваліметричними дослідженнями охоплено 90 зрубаних дерев віком від 59 до 99 років, висота яких змінювалась від 27,7 до 38,5 м; довжина ділової деревини стовбура знаходилась в межах 11,5-26,4 м. Встановлено особливості формування безсучкової зони дерева та зміну діаметрів у нижній частині стовбура, що істотно визначає якість лісоматеріалів загалом та класів А і В зокрема. Проаналізовано середню ширину річного кільця на $3 / 4$ радіуса периферійної деревини стовбура та наявність вади деревини "рогівка". Виявлено істотне збільшення вмісту пізньої деревини в річному кільці лісоматеріалів ялиці білої. Встановлено прямолінійну залежність між висотою дерева та окружностями лісоматеріалу: посередині, у нижньому та верхньому торцях. Досліджено залежності між довжиною безсучкової зони дерева та діаметром у нижньому торці лісоматеріалу, що характеризується помірним кореляційним зв'язком. Між віком дерева та діаметром несправжнього ядра виявлено високу тісноту зв'язку. Віковий чинник у поєданні з глобальними кліматичними змінами зумовлює збільшення не тільки кількості дерев із несправжнім ядром, але й площі пошкодження заболонної деревини ялиці білої. З'ясовано, що в досліджуваних ялицевих деревостанах діюча система лісогосподарювання зумовлює формування лісових екосистем з низькоякісною стовбурною деревиною.

Ключові слова: ялиця біла; кваліметрія деревини; лісоматеріали; вади деревини; ДП "Перечинське лісове господарство"; Українські Карпати.

Вступ. Глобальні кліматичні зміни зумовлюють сучасні еколого-економічні тренди щодо збереження лісових екосистем, в яких $є$ зростаюча загроза видовому різноманіттю та виникнення негативних екологічних наслідків (Schmidt, 2011; Gazol et al., 2015). При цьому лісівниче занепокоєння викликає те, що лісогосподарську діяльність переважно розглядають через екологічну призму, а зокрема відсоток природних лісів (Rigling \& Schaffer, 2015).

Розглядаючи глобальні підходи до майбутніх сценаріїв збереження біорізноманіття в лісових екосистемах, складно віднайти алгоритм прийняття невідкладних рішень у питаннях, пов'язаних із масовим ураженням та висиханням хвойних лісових насаджень. У цьому контексті особливої актуальності набувають такі питання: 1. Результативність сучасних методів ведення лісового господарства; 2. Динаміка кількості та площ деревостанів, яким загрожує всихання та ураження шкідниками й хворобами: 3. Еколого-економічне вирішення зазначених вище проблем.

Зрозуміло, що для локалізації будь-якої проблеми потрібні фінансові ресурси, отримання яких залежить насамперед від якості реалізованої лісопродукції. 3 огляду на це вирішення екологічних проблем доцільно пов'язувати з кваліметричними (якісними) характеристиками заготовленої деревини.

Варто зазначити, що екологічно збалансоване лісо- користування у країнах Європи, серед яких Швеція, Австрія, Польща, Швейцарія та інші країни (www.skogsstyrelsen.se; www.lasy.gov.pl), націлене на використання більше 90 \% щорічного приросту, що відповідає принципам сталого лісокористування. У товарознавчій площині це означає, що відсоток заготівлі високоякісної деревини (круглі лісоматеріали класів якості А та В) варіює від 50 до 80 \% залежно від деревостану. Орієнтовна заготівля аналогічних класів якості деревини в 2019 р., згідно із стандартами ДСТУ ЕN для Держлісагентства, становитиме $25 \%$ (http://dklg.kmu.gov.ua).

Мета роботи - дослідити лісівничі аспекти визначення якісно-розмірних характеристик стовбурної деревини ялиці білої у стиглих деревостанах Українських Карпат на прикладі Тур'я-Реметівського та Порошківського лісництв ДП "Перечинське лісове господарство".

Матеріал і методи дослідження. Для вивчення розмірно-якісних характеристик стовбурної деревини ялиці білої в експлуатаційних лісах Тур'я-Реметівського та Порошківського лісництв ДП "Перечинське лісове господарство" відібрано три ялицево-букові насадження, в яких зрубано 90 дерев відповідно до проведення санітарно-вибіркової рубки. Лісівничо-таксаційні показники досліджуваних ялицево-букових деревостанів, що росли на абсолютній висоті 300-400 м н.р.м., наведено в табл. 1.

\section{Інформація про авторів:}

Сопушинський Іван Миколайович, д-р с.-г. наук, професор, кафедра ботаніки, деревинознавства та недеревних ресурсів лісу.

Email: sopushynskyy@nltu.edu.ua

Кополовець Ярослав Михайлович, наук. співробітник, науково-дослідна частина. Email: plh@ukr.net

Цитування за ДстУ: Сопушинський І. М., Кополовець Я. М. Кваліметрія лісоматеріалів ялиці білої в Українських Карпатах.

Науковий вісник НЛтУ України. 2019, т. 29, № 7. С. 142-145.

Citation APA: Sopushynskyy, I. M., \& Kopolovets, Ya. M. (2019). Quality Assessment of Silver Fir Timber in the Ukrainian Carpathians. Scientific Bulletin of UNFU, 29(7), 142-145. https://doi.org/10.15421/40290728

142 Науковий вісник НЛТУ України, 2019, т. 29, № $7 \quad$ Scientific Bulletin of UNFU, 2019, vol. 29, no 7 
Табл. 1. Лісівничо-таксаційні показники ялицевих деревостанів

\begin{tabular}{|c|c|c|c|c|c|c|c|c|}
\hline \multirow{2}{*}{ 穿 } & \multirow{2}{*}{ 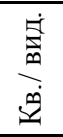 } & \multirow{2}{*}{$\begin{array}{c}\text { Склад } \\
\text { деревоста- } \\
\text { ну }\end{array}$} & \multirow{2}{*}{$\begin{array}{c}\text { Індекс } \\
\text { типу } \\
\text { лісу }\end{array}$} & \multirow{2}{*}{$\begin{array}{l}\text { Вік, } \\
\text { ро- } \\
\text { ків }\end{array}$} & \multirow{2}{*}{$\begin{array}{c}\text { Боні- } \\
\text { тет/Віднос- } \\
\text { на повнота }\end{array}$} & \multicolumn{2}{|c|}{$\begin{array}{c}\text { Серед- } \\
\text { ня }\end{array}$} & \multirow{2}{*}{$\begin{array}{c}\text { За- } \\
\text { пас, } \\
\mathrm{m}^{3} \cdot \Gamma \\
\mathrm{a}^{-1}\end{array}$} \\
\hline & & & & & & $\begin{array}{c}H, \\
\text { м }\end{array}$ & $D$, & \\
\hline \multicolumn{9}{|c|}{ тівське лісн } \\
\hline & $9 / 37$ & DNTI & & & & 33 & 40 & \\
\hline \multicolumn{9}{|c|}{ орошківське л } \\
\hline & & & & 72 & & 35 & 48 & \\
\hline & & & ГБ & 92 & IБ $/ 0$ & 33 & 36 & 430 \\
\hline
\end{tabular}

Примітки: $H$-середня висота; $D$ - середній діаметр.

Типи лісу визначено за лісотипологічною методикою, яку запропонував проф. 3. Ю. Герушинський (Неrushynskyy, 1996). Таксацію дерев і насадження проведено з використанням таксаційного довідника (Lisotaksatsijnyj dovidnyk, 2013), а для визначення класів якості деревини ялиці білої використано збірник технічних умов на класифікацію лісоматеріалів (Sbirnyk, 2019).

Результати дослідження. Потреба у достовірній інформації про розмірно-якісні показники відведених у рубку дерев та їх відповідність до якості заготовленої деревини $є$ змістовною складовою таксації дерев та кваліметрії деревини в лісогосподарському виробництві. Статистичну характеристику досліджуваних звалених дерев ялиці білої на відведених в рубку ділянках подано в табл. 1.

Кваліметрією охоплено 90 зрубаних дерев віком від 59 до 99 років. Діапазон висот зрубаних дерев зміню- вався від 27,7 до 38,5 м, у яких довжина ділової частини стовбура (ділової деревини) знаходилась в межах 11,526,4 м. Окружність лісоматеріалів у корі нижнього торця варіювала від 88 до 251 см. Задовільний показник точності $(P<5 \%)$ стверджує про те, що кількість дерев, взятих для товарознавчого дослідження лісоматеріалів ялиці білої, є статистично достовірною.

Табл. 1. Таксаційні показники досліджуваних дерев ялиці білої

\begin{tabular}{|c|c|c|c|c|c|}
\hline Показник & $\begin{array}{c}\text { Міні- } \\
\text { мальне } \\
\text { значен- } \\
\text { ня }\end{array}$ & $\begin{array}{c}\text { Середне } \\
\text { арифме- } \\
\text { тичне } \\
\text { значен- } \\
\text { ня }\end{array}$ & $\begin{array}{c}\text { Макси- } \\
\text { мальне } \\
\text { значен- } \\
\text { ня }\end{array}$ & $\begin{array}{c}\text { Коефі- } \\
\text { цієнт } \\
\text { варі- } \\
\text { ації, \% }\end{array}$ & $\begin{array}{c}\text { Показ- } \\
\text { ник } \\
\text { точ- } \\
\text { нос- } \\
\text { ті, \% }\end{array}$ \\
\hline Вік дерева, років & 59 & 84 & 99 & 15,8 & 2,4 \\
\hline Висота дерева, м & 27,7 & 33,3 & 38,5 & 7,3 & 1,1 \\
\hline $\begin{array}{c}\text { Довжина ділової } \\
\text { частини стовбу- } \\
\text { ра, м }\end{array}$ & 11,5 & 20,0 & 26,4 & 19,0 & 2,8 \\
\hline \multicolumn{6}{|c|}{ Окружність лісоматеріалів у корі, см } \\
\hline $\begin{array}{c}\text { у нижньому } \\
\text { торці, см }\end{array}$ & 88 & 159 & 251 & 27,6 & 4,1 \\
\hline $\begin{array}{c}\text { посередині лісо- } \\
\text { матеріалу, см }\end{array}$ & 63 & 116 & 195 & 28,9 & 4,3 \\
\hline $\begin{array}{c}\text { у верхньому } \\
\text { торці, см }\end{array}$ & 44 & 85 & 141 & 29,6 & 4,4 \\
\hline
\end{tabular}

Для вивчення впливу лісівничих чинників на норми сортування для деревини ялиці білої виміряно характерні морфологічні ознаки для лісоматеріалів, які визначають класи якості А, B, С та D (табл. 2).

Табл. 2. Якісно-параметричні показники лісоматеріалів

\begin{tabular}{|c|c|c|c|c|c|}
\hline Показник & $\begin{array}{c}\text { Мінімальне } \\
\text { значення }\end{array}$ & $\begin{array}{c}\text { Середнє арифметичне } \\
\text { значення }\end{array}$ & $\begin{array}{c}\text { Максимальне } \\
\text { значення }\end{array}$ & $\begin{array}{l}\text { Коефіцієнт ва- } \\
\text { ріації, \% }\end{array}$ & $\begin{array}{c}\text { Показник точ- } \\
\text { ності, \% }\end{array}$ \\
\hline \multicolumn{6}{|c|}{ Дерева віком до 75 років } \\
\hline Довжина ділової деревини, м & 13,7 & 19,8 & 23,0 & 11,6 & 3,1 \\
\hline Довжина окоренкуватості, м & 0,4 & 0,5 & 0,9 & 22,5 & 6,0 \\
\hline \multicolumn{6}{|c|}{ Діаметр лісоматеріалів без кори, см } \\
\hline у нижньому ториі & 26 & 33 & 42 & 13,7 & 3,6 \\
\hline посередині лісоматеріалу & 19 & 25 & 33 & 18,6 & 5,0 \\
\hline у верхньому ториі & 13 & 18 & 26 & 23,8 & 6,3 \\
\hline \multicolumn{6}{|c|}{ Відстань до, м } \\
\hline першого відмерлого сучка & 4,5 & 8,0 & 11,0 & 18,7 & 5,0 \\
\hline периої живої гілки & 6,0 & 8,9 & 12,0 & 16,3 & 4,4 \\
\hline \multicolumn{6}{|c|}{ Дерева віком більше 75 років } \\
\hline Довжина ділової деревини, м & 11,5 & 20,1 & 26,4 & 21,5 & 3,9 \\
\hline Довжина окоренкуватості, м & 0,5 & 1,1 & 2,0 & 29,4 & 5,3 \\
\hline \multicolumn{6}{|c|}{ Діаметр лісоматеріалів без кори, см } \\
\hline у нижньому ториі & 32 & 56 & 78 & 18,6 & 3,3 \\
\hline посередині лісоматеріалу & 24 & 41 & 61 & 21,6 & 3,9 \\
\hline у верхньому ториі & 17 & 30 & 44 & 22,7 & 4,1 \\
\hline \multicolumn{6}{|c|}{ Відстань до, м } \\
\hline першого відмерлого сучка & 2,0 & 5,2 & 12,0 & 38,2 & 6,9 \\
\hline периої живої гілки & 2,0 & 5,8 & 12,0 & 33,2 & 6,0 \\
\hline
\end{tabular}

Цифрові дані табл. 2 свідчать, що середнє значення довжини ділової деревини стовбура в обох вікових групах практично не відрізняються. Середнє значення діаметра лісоматеріалів у нижньому торці у групи дерев віком більше 75 років $є$ більшим на $41 \%$ порівняно 3 деревами віком до 75 років. Морфологічні ознаки лісоматеріалів вказують на особливості формування безсучкової зони дерева та зміни діаметрів у нижній частині стовбура ялиці білої. При цьому варто зазначити, що відстань до першого живого сучка у дерев віком до 75 років змінюється від 6,0 до 12,0 м і є на $35 \%$ більшою, ніж у групі дерев віком більше 75 років. Ця морфологічна ознака $\epsilon$ істотною при відборі лісоматеріалів класу якості А та В. Наступною ознакою є вада деревини окоренкуватість, яка зменшує довжину високоякіс- ного сортименту. У лісоматеріалах ялиці білої вона знаходиться в межах від 0,5 до $2,0 \mathrm{M}$.

До важливих структурних ознак, які $\epsilon$ критеріями для відбору високоякісних сортиментів належать властиві вади деревини та показники макроструктури, що характеризують однорідність як кольорових відтінків, так і структури деревини (табл. 3).

Як видно з табл. 3, середня ширина річних кілець на $3 / 4$ радіуса периферійної деревини стовбура зменшується від нижнього до верхнього торця лісоматеріалу. Максимальні значення річного приросту є більшими у групи дерев віком більше 75 років, що зумовлює зменшення класу якості від А до В. Важливо зазначити, що для лісоматеріалів 3 діаметрами несправжнього ядра більше 30 см встановлена вада деревини "м'яка гнилиз- 
на". Середнє значення показника вади деревини рогівка (твердошаруватість, крень) є меншим на декілька порядків у групи дерев віком до 75 років.

Табл. 3. Структурні ознаки деревини

\begin{tabular}{|c|c|c|c|}
\hline Показник & \begin{tabular}{|c|} 
Міні- \\
мальне \\
значення \\
\end{tabular} & \begin{tabular}{|c|} 
Середнє \\
арифметичне \\
значення \\
\end{tabular} & $\begin{array}{c}\text { Макси- } \\
\text { мальне } \\
\text { значення } \\
\end{array}$ \\
\hline \multicolumn{4}{|c|}{ Дерева віком до 75 років } \\
\hline \multicolumn{4}{|c|}{ Середній річний приріст, мм } \\
\hline у нижньому ториі & \begin{tabular}{|l|l}
2,0 \\
\end{tabular} & 3,4 & 5,0 \\
\hline $\begin{array}{c}\text { посередині } \\
\text { лісоматеріалу }\end{array}$ & 2,1 & 3,1 & 4,1 \\
\hline у верхньому ториі & 1,9 & 2,8 & 3,9 \\
\hline \multicolumn{4}{|c|}{ Діаметр несправжнього ядра, см } \\
\hline у нижньому ториі & \begin{tabular}{|l|l}
0 \\
\end{tabular} & 6 & 30 \\
\hline $\begin{array}{c}\text { посередині } \\
\text { лісоматеріалу }\end{array}$ & 0 & 1 & 13 \\
\hline у верхньому ториі & 0 & 1 & 9 \\
\hline Рогівка, \% & \begin{tabular}{|l|l}
0 & \\
\end{tabular} & 3 & 21 \\
\hline \multicolumn{4}{|c|}{ Дерева віком більше 75 років } \\
\hline \multicolumn{4}{|c|}{ Середній річний приріст, мм } \\
\hline у нижньому ториі & \begin{tabular}{|l|l|}
2,4 \\
\end{tabular} & 3,7 & 6,0 \\
\hline $\begin{array}{c}\text { посередині } \\
\text { лісоматеріалу }\end{array}$ & 2,1 & 3,3 & 4,6 \\
\hline у верхньому ториі & 1,8 & 2,9 & 3,9 \\
\hline \multicolumn{4}{|c|}{ Діаметр несправжнього ядра, см } \\
\hline у нижньому ториі & \begin{tabular}{|l|l}
3 & \\
\end{tabular} & 36 & 64 \\
\hline $\begin{array}{c}\text { посередині } \\
\text { лісоматеріалу }\end{array}$ & 3 & 17 & 42 \\
\hline у верхньому ториі & 1 & 8 & 22 \\
\hline Рогівка, \% & 4 & 13 & 23 \\
\hline
\end{tabular}

Обговорення результатів дослідження. Першочерговий інтерес для лісогосподарського та деревообробного виробництв має стовбур, базовими характеристиками якого є діаметр та висота. Знання залежності між згаданими показниками дають змогу прогнозувати вихід високоякісних лісоматеріалів (рис. 1).

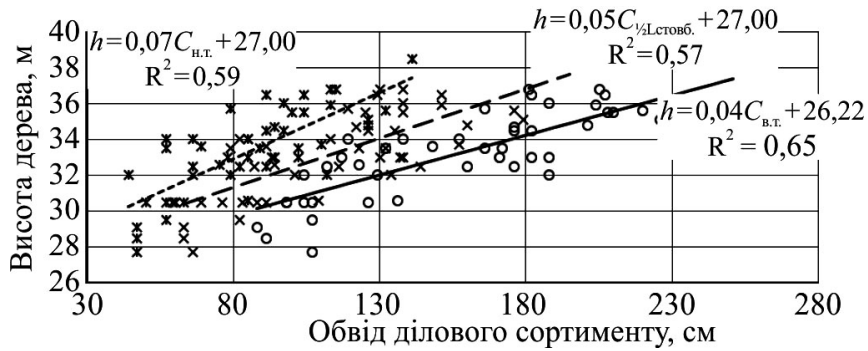

Рис. 1. Залежність висоти дерева від окружності посередині, у нижньому та верхньому торцях лісоматеріалу

Як видно з рис. 1, між висотою дерева та окружностями посередині, у нижньому та верхньому торцях ділового лісоматеріалу існує прямолінійна залежність. Найбільший коефіцієнт детермінації $\left(R^{2}=0,65\right)$ характерний для залежність між висотою дерева та окружністю нижнього торця лісоматеріалів і описується рівнянням першого порядку $h=0,04 C_{6 . m .}+26,22$.

Для того, щоб зрозуміти зв'язок між розмірно-якісними характеристиками стовбурів та лісоматеріалів ялиці білої потрібно проаналізувати вплив ознак норм сортування на класи якості деревини. Однією з визначальних ознак візуальної оцінки класу якості деревини $\epsilon$ діаметр лісоматеріалу в нижньому торці $\left(d_{t . m .}\right)$, довжина окоренкуватості $\left(l_{\text {ок. }}\right)$, відстань до першого живої гілки $\left(l_{\text {ж... }}\right)$ та відмерлого сучка $\left(l_{\text {s.c. }}\right)$, а також довжина ді-

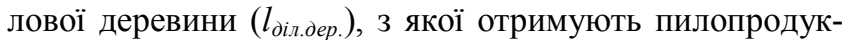
цію різноманітного призначення (рис. 2).

Аналіз морфологічних ознак вказує, що діаметр лісоматеріалів у верхньому торці істотно визначає їх роз- мірні характеристики. Залежність між діаметром дерева у нижньому торці та довжиною ділової деревини описується рівнянням прямої першого порядку $\left(l_{\text {діл.дер. }}=0,12 d_{\text {н.m. }}+16,06 ; R^{2}=0,56\right)$. При цьому важливо зазначити, що діаметр у нижньому торці дерева (лісоматеріалу) визначено на відстані, де закінчувалась вада деревини окоренкуватість. Аналогічну залежність отримано між діаметром лісоматеріалу в нижньому торці та довжиною окоренкуватості дерева $\left(l_{\text {ок. }}=0,02 x-0,09\right.$; $\left.R^{2}=0,57\right)$.

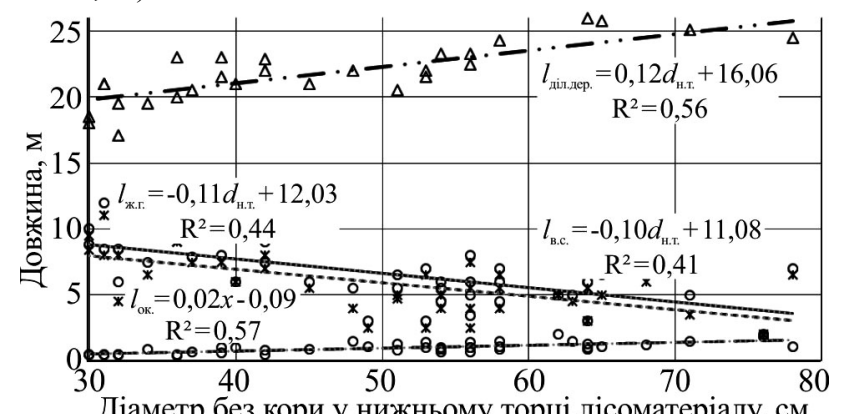

Діаметр без кори у нижньому торці лісоматеріалу, см

Рис. 2. Залежність морфологічних ознак від діаметра лісоматеріалу в нижньому торці

Між довжиною безсучкової зони дерева та діаметром у нижньому торці лісоматеріалу встановлено помірний кореляційний зв'язок $\left(R^{2}=0,41-0,44\right)$. Низькі значення коефіцієнта детермінації доцільно пов'язати зі значним віковим діапазоном досліджуваних дерев, а саме від 59 до 99 років. Аналіз отриманих даних вказує також на те, що дерева відрізнялись за діаметром та висотою і відмінністю візуальних ознак.

Отже, морфологічні ознаки дерева впливають на клас якості лісоматеріалів, але своєчасне проведення лісогосподарських заходів може зменшите їх вплив. Більш істотними ознаками є структурні відмінності деревини. До них відносять типові вади деревини ялиці білої: рогівку $\left(r_{\text {рог. }}\right)$ та величину річного приросту $(S)$ (рис. 3).

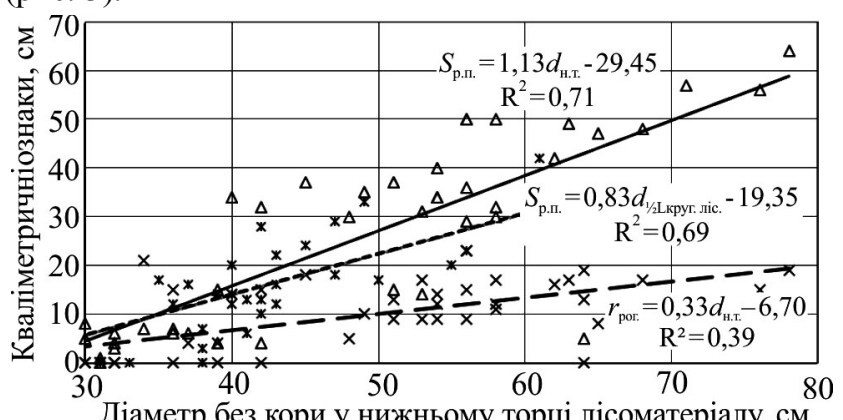

Діаметр без кори у нижньому торці лісоматеріалу, см

Рис. 3. Залежність кваліметричних ознак від діаметра лісоматеріалу в нижньому торці

Графічні дані рис. 3 підтверджують значну $\left(R^{2}=0,69\right)$ та високу $\left(R^{2}=0,71\right)$ залежність між річним приростом та діаметром без кори у нижньому торці лісоматеріалу. Встановлено також помірну залежність між вадою деревини рогівкою та діаметром без кори у нижньому торці лісоматеріалу $\left(r_{\text {рог. }}=0,33 d_{\text {н.m. }}-6,70 ; R^{2}\right.$ $=0,39)$.

Наявність кольорових відтінків у заболонній деревині або утворення несправжнього ядра вказує на наявність твердої та м'якої гнилизни і зменшує якість лісоматеріалів до класів C та D. Залежність діаметрів несправжнього ядра в стовбурі від віку дерева наведено на рис. 4. 


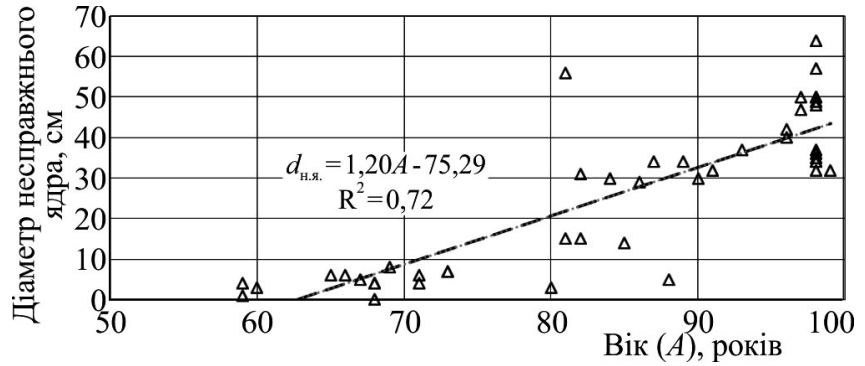

Рис. 4. Залежність між діаметром несправжнього ядра та віком дерева

Регресійна залежність між діаметрами несправжнього ядра у стовбурі та віком дерева характеризується високою тіснотою зв'язку $\left(R^{2}=0,72\right)$. Очевидно, що віковий чинник у поєданні 3 глобальними кліматичними змінами зумовлюють не тільки збільшення кількості дерев із несправжнім ядром, але й площі пошкодження заболонної деревини ялиці білої.

Аналіз наведеного фактологічного матеріалу вказує на те, що розмірно-якісні ознаки ялиці білої істотно змінюються у віковому діапазоні від 59 до 99 років. Візуальна оцінка якості ростучих дерев свідчить про високу частку ділової деревини, яка має довжину від 11,5 до 26,4 м. Однак детальний аналіз сортовизначальних вад деревини ялиці білої свідчить про значне зниження якості лісоматеріалів у дерев віком більше 75 років. До вад деревини, які зменшують класи якості деревини А, B та C, належить діаметр несправжнього ядра, ширина річного приросту та наявність рогівки.

Наведені вище факти дають підстави говорити про те, що кліматичні зміни на абсолютних висотах 300400 м н.р.м. в Українських Карпатах істотно впливають на якісні ознаки лісоматеріалів ялиці білої віком більше 75 років. У контексті науково-виробничої діяльності доцільно відзначити, що сучасні тенденції лісового виробництва в Україні спрямовані: - на збереження лісових екосистем 3 низькоякісною стовбурною деревиною; - на проведення лісівничих заходів, які сприяють росту та розвитку ялицевих деревостанів за участю дерев ялиці білої із малою біологічною стійкістю (із несправжнім ядром).

Висновки. За результатами дослідження лісівничих аспектів кваліметрії ялиці білої в Українських Карпатах встановлено про істотну зміну якості деревини у віці від 59 до 99 років. Відмінності формування якісних ознак лісоматеріалів дають підстави стверджувати про істотні зміни якості деревини у дерев віком більше 75 років, в яких діаметр несправжнього ядра займає більшу частину радіуса. Менший річний приріст характерний для групи дерев віком менше 75 років та змінюється від 2,0 до 5,0 мм. 3 огляду на отримані результати можна зробити припущення про значний вплив глобального потепління на якісні характеристики деревини ялиці білої, а діюча система лісогосподарювання в ялицевих деревостанах зумовлює формування лісових екосистем 3 низькоякісною стовбурною деревиною. Для лісогосподарського виробництва викликом залишається розроблення нових лісівничих підходів щодо вирощування деревостанів із високоякісною стовбурною деревиною.

\section{Перелік використаних джерел}

Gazol, A. J., Camarero, J., Gutieerrez, E., et al. (2015). Distinct effects of climate warming on populations of silver fir (Abies alba) across Europe. Journal of Biogeography, 42(6), 1150-1162. https://doi.org/10.1111/jbi.12512

Herushynskyy, Z. Yu. (1996). Typolohiya lisiv Ukrainskych Karpat. Lviv: Piramida. [In Ukrainian].

Lisotaksatsijnyj dovidnyk. (2013). Kiev: Publishing House "Vinichenko". [In Ukrainian].

Rigling, A., \& Schaffer, H. P. (Eds). (2015). Forest Report 2015. Condition and Use of Swiss Forests. Federal Office for the Environment, Bern, Swiss Federal Institute WSL, Birmensdorf, 144 p.

Sbirnyk tekhnichnykh umov na klasyfikacjyu lisomaterialiv. (2019). Kiev: DP "Lisohospodarskyi innovacijnyj centr". [In Ukrainian].

Schmidt, O. (2011). Waelder im Klimawandel - Weisstanne und Kuestentanne. Freising: LWF Wissen, $66 \mathrm{p}$.

I. M. Sopushynskyy, Ya. M. Kopolovets Ukrainian National Forestry University, Lviv, Ukraine

\section{QUALITY ASSESSMENT OF SILVER FIR TIMBER IN THE UKRAINIAN CARPATHIANS}

The current ecological and economic trend of the sustainable forestry is driven by the climate change that threatens the species diversity of forest ecosystems. In the forestry, it is very difficult to find an algorithm for solving problems related to mass dieback and drying of coniferous forest plantations in the Ukrainian Carpathians. To locate any problem, financial resources are required, the main share of which is obtained in the forestry through the sale of harvested high value quality timbers. For this reason, it is advisable to associate environmental concerns with the volume of harvested high value quality timbers. The aim of the study was to investigate the forest aspects of determining the qualitative-dimensional characteristics of stemwood of Silver fir stands of the Ukrainian Carpathians. Dimensional-qualitative characteristics of Silver fir stemwood in the operational forests of Turya-Remetiv and Poroshkiv districts of Perechyn Forestry SE are provided in the article. The study of wood quality assessment covered 90 cut down trees from 59 to 99 year old, whose height varied from 27.7 to $38.5 \mathrm{~m}$; the length of the business wood was in the range of 11.5-26.4 m. The peculiarities of formation of branchless wood of the tree and the change of diameters in the stem base of the timber were investigated, which significantly determines the quality classes A and B of timbers. The average width of the annual rings on the $3 / 4$ radius of the peripheral stem wood and the presence of reaction wood were analysed. A significant increase in the content of late wood in the annual ring of timber of Silver fir was found. A linear relationship between the height of the tree and the circles was established to be as following: in the middle, in the butt and upper ends of the timber. The relationships between the length of the branchless wood of the tree and the diameter at the butt end of the timber, characterized by a moderate correlation, were investigated. A high bond was found in the butt stem diameter and the age of the tree. The age-old factor, combined with global climate change, causes not only an increase in the number of trees with a wood fault core, but also the area of wood damage to Silver fir trunks. It has been found that in the studied fir stands, the current forest management system is aimed at preserving forest ecosystems with low wood quality trees.

Keywords: Silver fir; wood qualimetry; timber; wood defects; Perechyn Forestry SE; the Ukrainian Carpathians. 